\title{
Arthropod cuticles from the upper Viséan (Mississippian) of eastern Germany
}

\author{
JoAchim T. Haug, Maren HÜBers, Carolin haug, Andreas MaAs, Dieter Waloszek, \\ JÖRG W. SCHNEIDER \& HANS KERP
}

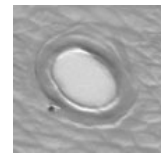

\begin{abstract}
Arthropod cuticles from the Mississippian (Early Carboniferous, Viséan) Hainichen Subgroup, Erzgebirge Basin, have been encountered in bulk-macerated samples from a roadcut exposure in Chemnitz-Glösa, eastern Germany. The cuticles are described in detail and compared with larger faunal components known from the same horizons. Part of the specimens represent remains of arthropod appendages, while others, though exhibiting fine detail of surface texture, could not be assigned to certain body regions. In all cases it remains difficult to assign the fragments from Chemnitz-Glösa to taxa known from the Hainichen Subgroup or from other localities yielding arthropod remains of similar preservation. However, it is suggested that several specimens may represent scorpion remains, either limb parts (piece of the pedipalp, distal claw of walking limb) or fragments of the body surface. One specimen, a single appendage element, could represent the first insect fragment from this locality. All fragments appear to be terrestrial faunal components. Chemnitz-Glösa is one of the very few Lower Carboniferous localities to yield remains of terrestrial arthropods and the only one outside Scotland. Key words: Mississippian, Lower Carboniferous, arthropod cuticles, Erzgebirge Basin.
\end{abstract}

Haug, J.T., Hübers, M., Haug, C., MaAs, A., WaloszeK, D., Schneider, J.W. \& KerP, H. 2014. Arthropod cuticles from the upper Viséan (Mississippian) of eastern Germany. Bulletin of Geosciences 89(3), 541-552 (7 figures). Czech Geological Survey, Prague. ISSN 1214-1119. Manuscript received September 20, 2013; accepted in revised form January 13, 2014; published online May 6, 2014; issued June 9, 2014.

Joachim T. Haug (corresponding author) \& Carolin Haug, LMU Munich, Biocenter - Department of Biology II and GeoBio-Center, Großhaderner Straße 2, 82152 Planegg-Martinsried, Germany; joachim.haug@ palaeo-evo-devo.info - Maren Hübers \& Hans Kerp, Forschungsstelle für Paläobotanik, Institut für Geologie und Paläontologie, Westfälische Wilhelms-Universität Münster, Heisenbergstraße 2, 48149 Münster, Germany • Andreas Maas \& Dieter Waloszek, AG Biosystematische Dokumentation, Universität Ulm, Helmholtzstraße 20, 89081 Ulm, Germany •Jörg W. Schneider, TU Bergakademie Freiberg, Geologisches Institut, Bernhard-von-Cotta-Straße 2, 09596 Freiberg, Germany and Kazan Federal University, Kremlevskaya st. 18, 420008 Kazan, Russian Federation

The middle Mississippian Hainichen Subgroup comprises the oldest terrestrial erosional debris ("Early Molasses") of the Variscan Orogen in eastern Germany. These mostly coarse clastics have been deposited in the Hainichen Subgroup of the Hainichen Basin, which is part of the Carboniferous-Permian Erzgebirge Basin (Fig. 1; Schneider et al. 2005). The Hainichen Subgroup is divided into two formations (Fig. 2). The lower one, the Ortelsdorf Formation, is dated as Viséan 3b (Asbian), the upper one, the Berthelsdorf Formation, is dated as Viséan 3c (Brigantian) (Gaitzsch et al. 2010). Both formations have yielded a rich and diverse flora, which has been described, by, e.g., Rothpletz (1880), Sterzel (1884), Máyas (1920) and Hartung (1938). The plant material mainly comes from the Ortelsdorf Formation and was sampled in dumps of coal mines between Hainichen and Chemnitz. These coal mines were active during the $18^{\text {th }}$ century. Additional material was sampled in sand and clay pits of the Berthelsdorf formation near Chemnitz. The faunal record, including adpressions of arachnids, myriapods, arthropleurids, eurypterids, shark egg capsules and single isolated fish remains (Nindel 1955, Rößler \& Schneider 1997) has exclusively been described from the Berthelsdorf Formation until 2001 (Schneider et al. 2005). During the reconstruction of the A4 federal motorway near Chemnitz-Glösa from 2001 to 2003 extensive collection of fossil plants and animals was possible in the Ortelsdorf Formation. The preservation of fossil arthropods in general is, however, not restricted to adpressions. Several arthropod cuticles were described from the Palaeozoic, mainly from the Devonian (e.g., Størmer 1970, 1976; Rolfe 1980; Shear et al. 1984) and Pennsylvanian (e.g., Winslow 1959, Bartram et al. 1987, Jeram 1994a, Braun 1997, Stankiewicz et al. 1998). Cuticles can provide additional information on morphological features, which cannot be gained in such detail from adpression remains. Also bulk maceration of samples from the Ortelsdorf Formation 


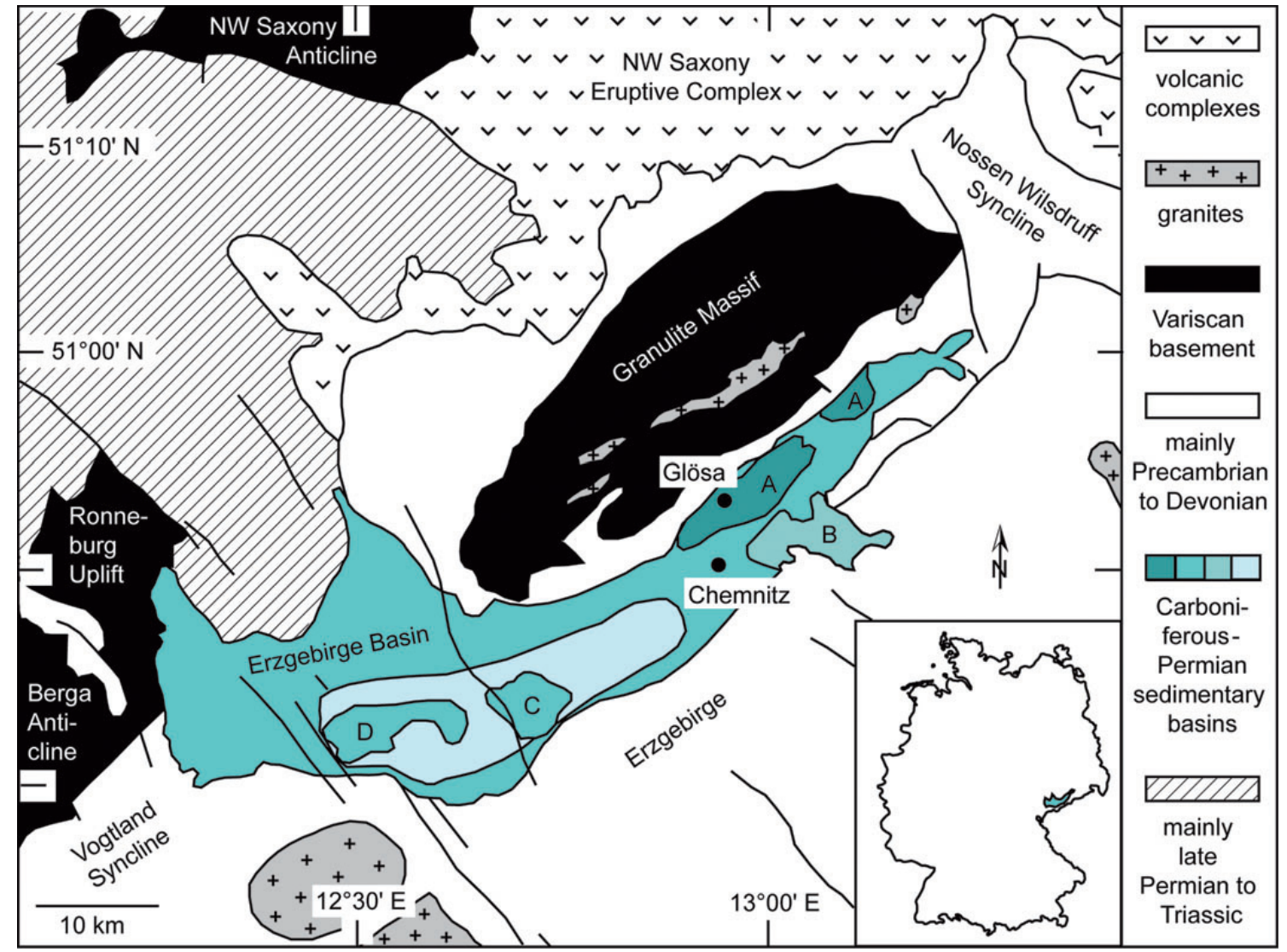

Figure 1. Position of the Mississippian Hainichen Basin (A) and the Pennsylvanian-Permian Erzgebirge basins (B: Flöha Basin, C-D: Zwickau-Oelsnitz Basin) in eastern Germany (after Schneider \& Romer 2010, their fig. 8).

yielded several arthropod cuticles, which are described in this paper. We compare these cuticles with other fossil and extant arthropod material and try to align them with macroscopic remains already described from the Hainichen Subgroup.

\section{Locality, material and methods}

Eleven samples from different plant detritus-rich horizons and carbonaceous shales of decimeter thickness were collected in the upper Ortelsdorf Formation in ChemnitzGlösa (505 $\left.52^{\prime} 34.67^{\prime \prime} \mathrm{N} ; 12^{\circ} 54^{\prime} 38.73^{\prime \prime} \mathrm{E}\right)$. The specimens described here were collected from a roadcut of the A4 federal motorway near Chemnitz-Glösa, Free State of Saxony, Germany, where a $80 \mathrm{~m}$ thick succession of Mississippian sandstones, shales and occasional coaly layers of the upper part of the Ortelsdorf Formation, Hainichen Subgroup, Hainichen Basin, is exposed (Schneider et al. 2005). The Hainichen Basin is a small basin, filled with alluvial plain, alluvial fan and fan delta deposits. The upper Ortelsdorf Formation at Glösa has been dated palynologically (Jäger \& Wierich 2006) and comprises the NM and VF zones of the palynological standard zonation of Clayton $e t$ al. (1977). The samples are from the uppermost part which is late Viséan (early Brigantian) in age (VF Zone) (Fig. 2). Although the single-Zircon $\mathrm{Pb} / \mathrm{Pb}$ evaporation age of $330 \pm 4$ Ma of a rhyolithic tuff at the base of the coalbearing fossiliferous upper part of the formation (Gehmlich et al. 1998, Gaitzsch et al. 2010) is not very precise, it is consistent with the palynological dating. Coalification in the Hainichen Basin is low (sub-bituminous coals; $\left.\mathrm{R}_{\mathrm{m}} \sim 0.5\right)$. In the first half of the $20^{\text {th }}$ century outcrops yielded one of the very few Viséan macrofloras with Archaeocalamites radiatus, Lepidodendron lossenii and Lyginopteris bermudensiformis as common elements (Hartung 1938). The shales exposed near Glösa contain abundant organic debris, mainly plants including lycopsids (Hübers et al. 2011) and the oldest mosses (Hübers \& Kerp 2012, Hübers et al. 2013). Some of the samples contain macroscopic plant remains of the seed fern Lyginopteris bermudensiformis and the lycophyte Lepidodendron lossenii. Macroscopic faunal remains could not be observed in the samples, but have been discovered during outcrop documentation 2001-2002.

Bulk maceration with $48 \%$ hydrofluoric acid yielded many small plant fragments. Small pieces of sample 2324/2004 were carefully removed from the surface and dissolved in $48 \%$ hydrofluoric acid; all other samples were 
dissolved completely. Cuticle preparation was carried out as described by Kerp (1990) and Kerp \& Krings (1999). Isolated cuticles were macerated using Schulze's reagent $\left(\mathrm{HNO}_{3}+\mathrm{KClO}_{3}\right)$, treated with a $4 \%$ potassium hydroxide solution $\left(\mathrm{KOH}_{\mathrm{aq}}\right)$, dehydrated in glycerol and finally mounted on microscope slides using glycerine jelly. The slides are stored in the collection of the Forschungsstelle für Paläobotanik at the Institut für Geologie und Paläontologie, Westfälische Wilhelms-Universität Münster, Germany.

For comparison, different fossil and extant arthropods were studied. This includes isolated legs of an undetermined pseudoscorpion, Brachistosternus sp. (Scorpiones, Chelicerata), Scutigera coleoptrata (Chilopoda, Myriapoda), and Oniscus asellus (Isopoda, Crustacea), which were macerated in $10 \% \mathrm{KOH}$ for two weeks. (The cuticle of a zygentoman insect treated in the same way proved to be too much damaged for further processing.) The (remaining) cuticles were rinsed in water, placed between two glass slides and left there for drying. This procedure was used to obtain comparable data from extant specimens, as it is supposed to partly resemble the taphonomic and preparational history of Glösa arthropod remains. Subsequently the dried specimens were documented using a Zeiss Axioskop microscope equipped with a SkopeTek DCM 510 ocular camera under transmitted polarized light. Images were recorded in the form of stacks, several for each specimen. These stacks were fused with Combine ZM and Combine ZP. The fused images were then stitched with Adobe Photoshop CS3 or Microsoft Image Composite Editor (details on procedure in Haug et al. 2009).

For an overview of taxa possibly represented by the cuticle remains from Glösa, different arthropods from the Upper Carboniferous Mazon Creek Lagerstätte, Illinois, USA (ROM 43581 trigonotarbid; ROM 45545 Geralinura carbonaria, thelyphonid whip scorpion; ROM 45559 scorpion; ROM 45571 Latzelia primordialis, scutigeromorph centipede; ROM 47504 Hesslerella shermani, aquatic isopod; ROM 61543 pterygote insect; ROM 61608 diplopod; ROM 61541 Dasyleptus sp., archaeognath) and Early Permian Carrizo Arroyo deposits, New Mexico, USA (ROM 57075 Dasyleptus sp.) from the collection of the Royal Ontario Museum (ROM) Toronto were documented under polarized light with a Canon Rebel T3i camera and an MP-E $65 \mathrm{~mm}$ macro lens. Also several stacks were obtained from each specimen and processed as described above. Additionally, an isolated appendage fragment of a trigonotarbid specimen from the Devonian Rhynie Chert, Scotland (RRC 3702, Remy Rhynie Chert Collection at the Forschungsstelle für Paläobotanik, Münster) and leg details of different insect specimens [ROM 63044 (AI 190) grylloid; ROM 63045 (AI 459) blattoid; ROM 63046 (AI 751) tettigoniid; ROM 63047 (AI 2649) orthopteran; ROM 63048 (AI 3211) notonectid heteropteran] from the Cretaceous Crato Formation, Brazil

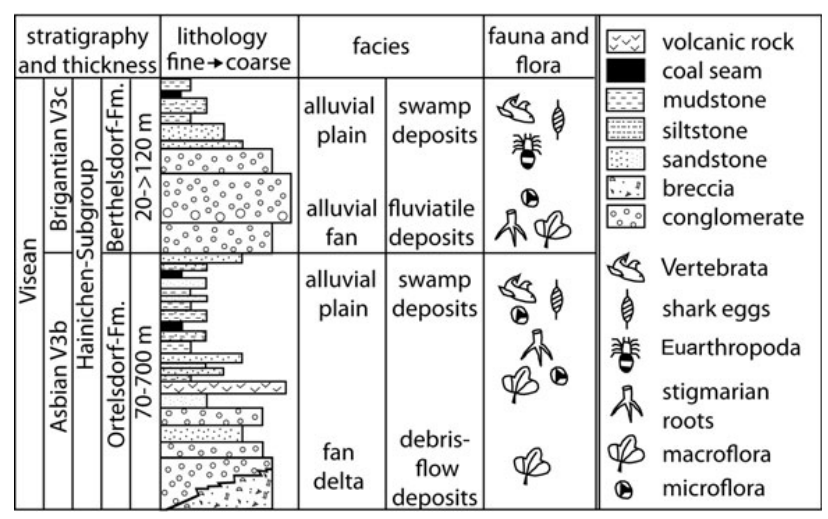

Figure 2. Age, subdivision, facies pattern and fossil content of the Hainichen Subgroup (after Gaitzsch et al. 2010, their fig. 3).

(property of the Axelrod Institute, University of Guelph, on long term loan to the ROM) were documented as these provide fine details of different appendages. Specimens from Crato were documented in the same way as those from Mazon Creek. The specimen from the Rhynie Chert was documented with transmitted light on a Zeiss Axioskop 2 equipped with a grey-scale AxioCam. An image stack was recorded and projected as a minimum intensity projection using the software ImageJ.

\section{Description of the arthropod cuticles}

\section{Arthropod appendage elements}

The samples from Glösa contain four cuticular remains of different arthropod appendage elements:

- Specimen "Glösa-2324/2004-018" (Fig. 3A): Appendage element, ca $1100 \mu \mathrm{m}$ long, width increasing from proximal to distal end, up to $400 \mu \mathrm{m}$. Surface exhibiting pore-like structures, $c a 10 \mu \mathrm{m}$ in diameter, which may represent insertions of setae. Three distal movable elements, $446 \mu \mathrm{m}, 390 \mu \mathrm{m}$ and $227 \mu \mathrm{m}$ long. Triangular movable setae (60-70 $\mu \mathrm{m}$ long) arranged in two rows.

- Specimen “Glösa-Profil KS11-099” (Fig. 3B): Presumably terminal sickle-shaped claw, about $820 \mu \mathrm{m}$ long. Two smaller spines arise medio-proximally from the claw.

- Specimen "Glösa-Profil KS27-101” (Fig. 3C): Appendage element, $c a 690 \mu \mathrm{m}$ long and $400 \mu \mathrm{m}$ wide. Surface exhibits pore-like structures, probably hair bases; some hairs still attached.

- Specimen "Glösa-Profil KSgr.Pr.-056” (Fig. 3D): Presumably terminal appendage element, ca $1.65 \mathrm{~mm}$ long, up to $170 \mu \mathrm{m}$ wide, arcuate. Small serrations on concave lateral side of the limb. Serrations up to $25 \mu \mathrm{m}$ long. Surface rough. No special structures present. 

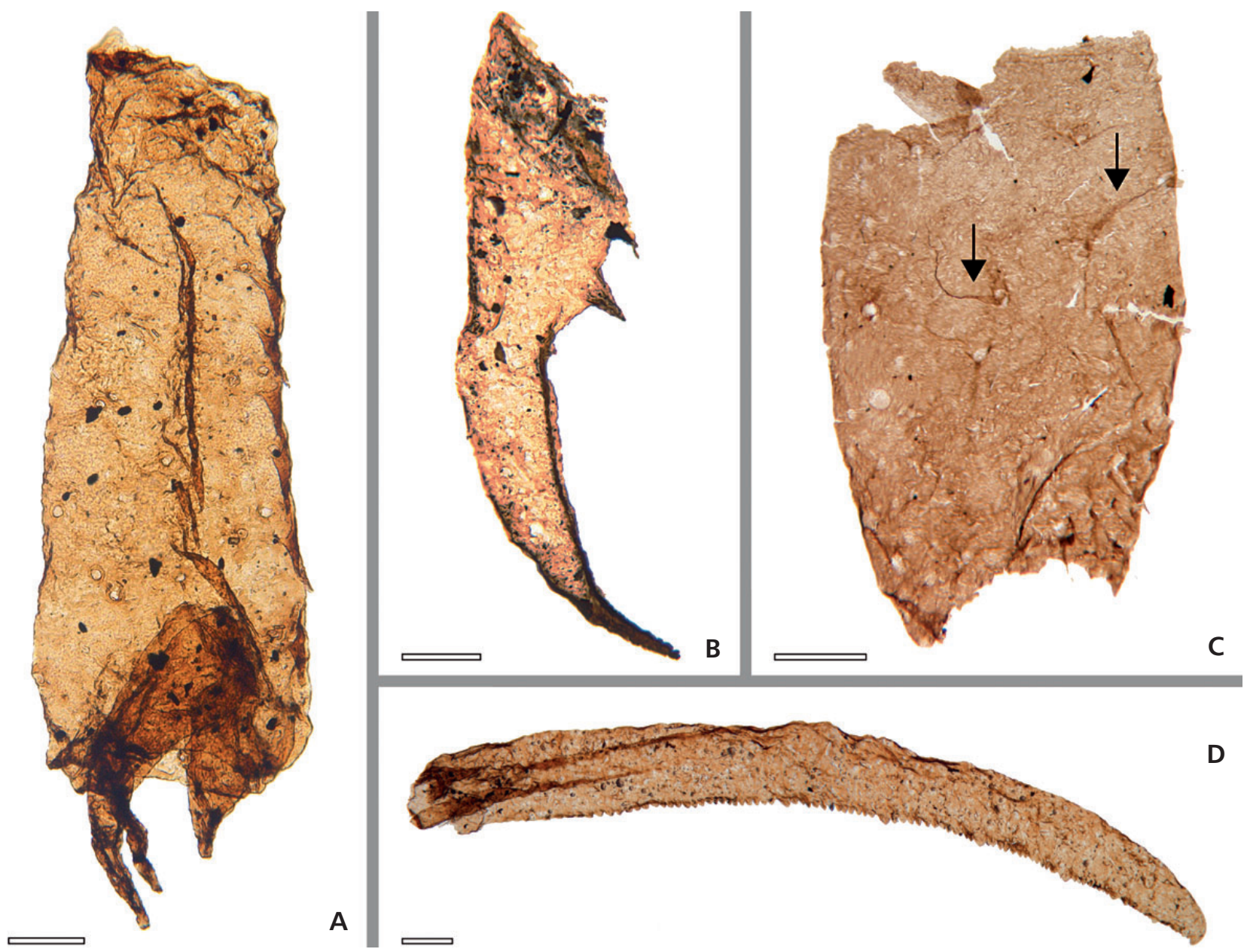

Figure 3. Arthropod appendage elements. $•$ A - Glösa-2324/2004-018. Appendage element with distal movable elements and triangular movable setae, scale bar $=100 \mu \mathrm{m} . \bullet \mathrm{B}-$ Glösa-Profil KS11-099. Claw with denticles, scale bar $=100 \mu \mathrm{m}$. $\bullet \mathrm{C}-$ Glösa-Profil KS27-101. Arthropod appendage element showing hairs (indicated by arrows), scale bar $=100 \mu \mathrm{m}$. D - Glösa-Profil KSgr.Pr.-056. Sickle-shaped element with serrations, scale bar $=100 \mu \mathrm{m}$.

\section{Other arthropod cuticle fragments}

The samples from Glösa also contain several fragments of arthropod cuticle, which cannot be assigned to certain body parts. However, their well-preserved surfaces exhibit many structural details.

- Arthropod Cuticle Type 1: Glösa-Profil KS62/2-037 to $-041,-043$ to $-053,-056,-057,-061$; Glösa-Profil KSgr.Pr.-014, -043, -060; Glösa-Profil KS 11-016, -038, -092; Glösa-Profil KS27-105; Glösa-Profil KS34/35-024 (Fig. 4A-D): Cuticle fragments with isodiametric structure and more or less regularly arranged pores. Pores generally $15-20 \mu \mathrm{m}$ in diameter, sometimes containing hair bases (Fig. 4B), largest pore $161 \mu \mathrm{m}$ in diameter with remnants of thin cuticle at the margin (Fig. 4D). Some specimens exhibiting small papillae (Fig. 4C). Papillae $c a 3 \mu \mathrm{m}$ in diameter.

- Arthropod Cuticle Type 2: Glösa-Profil KS62/2-001, -003, -004, -030, -031; Glösa-2324/2004-095 (Fig. 4E-G): Thick cuticle with strong sclerotization and rough tubercular surface, occasionally with pore-like structures (Fig. 4F).

Figure 4. Arthropod Cuticle Type 1 and Arthropod Cuticle Type 2. • A - Glösa-Profil KS62/2-040. Arthropod Cuticle Type 1, overview showing isodiametric structure and pores, scale bar $=100 \mu \mathrm{m}$. $\bullet \mathrm{B}-$ detail of A, showing pore with hair base, scale bar $=10 \mu \mathrm{m}$. $\bullet \mathrm{C}-\mathrm{Glösa}-\mathrm{Profil} \mathrm{KS} 62 / 2-041$. Arthropod Cuticle Type 1 showing small papillae (indicated by arrows), scale bar $=10 \mu \mathrm{m}$. $\bullet \mathrm{D}-$ Glösa-Profil KS62/2-061. Arthropod Cuticle Type 1 showing exceptionally large pore with remnants of thin cuticle at the margin, scale bar $=100 \mu \mathrm{m}$. $\bullet$ E - Glösa-Profil KS62/2-001. Arthropod Cuticle Type 2, overview showing rough tubercular surface, scale bar $=100 \mu \mathrm{m}$. $\bullet \mathrm{F}-$ detail of D, showing pore-like structures, scale bar $=100 \mu \mathrm{m}$. $\bullet \mathrm{G}-\mathrm{Glösa-Profil}$ KS62/2-003. Arthropod Cuticle Type 2, specimen showing differences in strength of sclerotization, scale bar $=100 \mu \mathrm{m}$. 

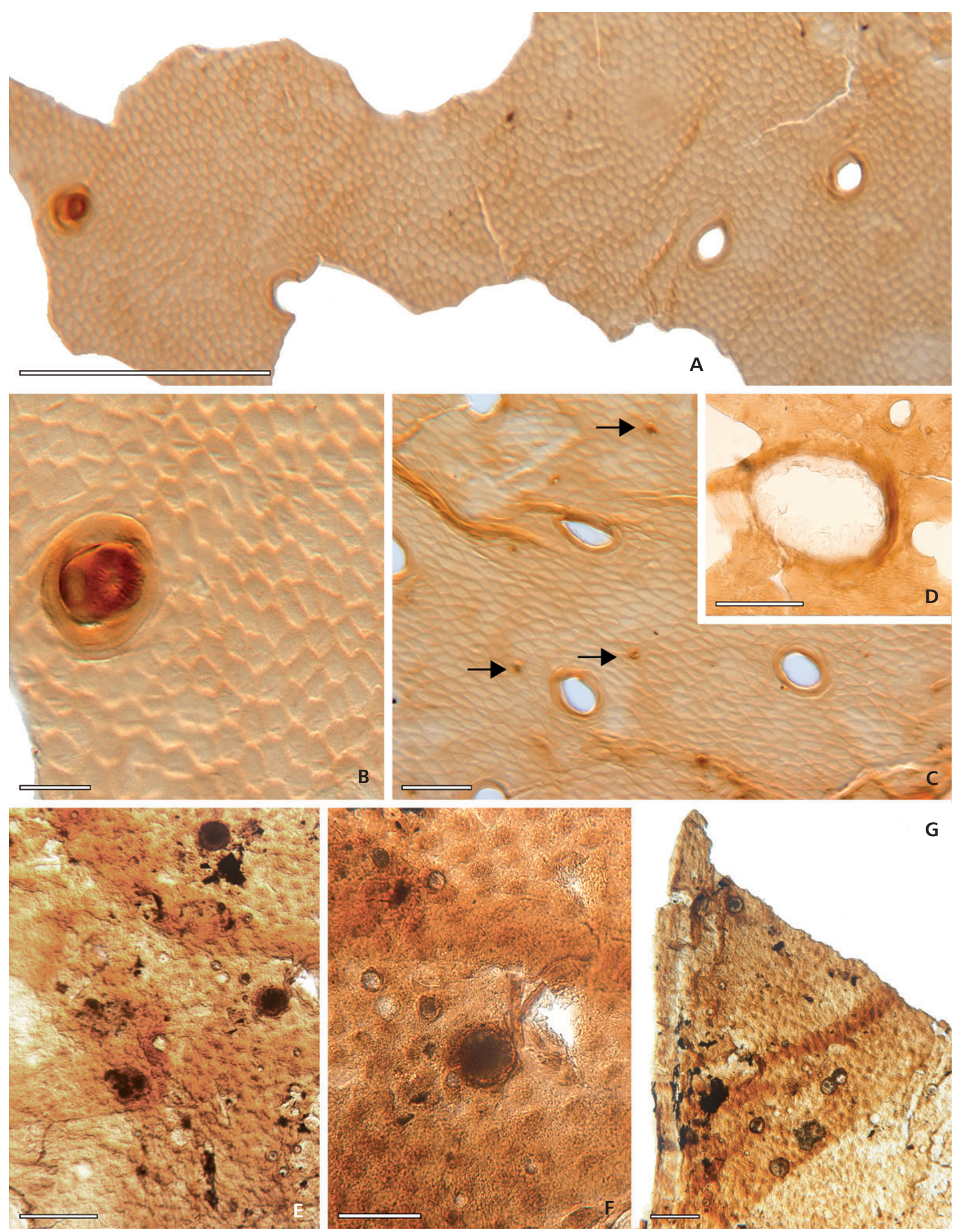


\section{Discussion of the arthropod cuticle fragments}

While cuticle fragments can provide quite different data compared to adpression fossils of arthropods, identifying the taxonomic affinities of the cuticle fragments can be challenging. In this case the investigation of the few cuticle fragments is an important task, due to the stratigraphic origin of the specimens. The Carboniferous is a crucial period for the diversification of terrestrial arthropods in particular, including chelicerates, insects and myriapods (e.g., Rolfe 1980, Rasnitsyn \& Quicke 2002, Grimaldi \& Engel 2005). Chelicerates are represented by various already specialized groups such as true scorpions (Fig. 5A) and the once diverse, but now extinct Trigonotarbida (Fig. 5B), but also by less well-known taxa such as Thelyphonida, the whip scorpions (Fig. 5C). While the Hainichen Subgroup also yielded remains of aquatic arthropods, i.e. Eurypterida, the cuticle fragments described here do not appear to represent remains of eurypterids. Insects are well represented by non-flying forms, such as Archaeognatha (Fig. 5E), but especially by pterygote insects (Fig. 5D), which are an important part of the Carboniferous faunas. Myriapods are represented by in-groups of Chilopoda, such as Scutigeromorpha (Fig. 5F), but also Diplopoda are well represented (Fig. 5G). Another terrestrial group of arthropods, the wood lice (Isopoda), an in-group of Eucrustacea, have not been found in the Carboniferous yet, although aquatic isopods make their appearance in the Carboniferous (Fig. 5H).

Accordingly, the Glösa cuticles could be remains of any of the representatives of the terrestrial groups, although until now mainly chelicerates and myriapods are known from the same locality. Possible affinities are discussed for each specimen in the following.

Specimen "Glösa-2324/2004-018" (Fig. 3A) could be interpreted as representing the sub-terminal element of an appendage with a putative terminal claw. Yet, it does not bear a single terminal element, but there are three movable ones. This morphology would be unusual for a terminal structure. Additionally, the distal opening of the large element is significantly larger than the three small elements, and much more likely accommodated a further terminal limb element. It is also difficult to judge if the three small elements lie "inside" the large element, i.e. between two cuticle layers, which would point to a true terminal claw, or whether they lie outside, representing equivalents of strong movable setal elements.

Besides this uncertainty about the true nature of these supposed terminal structures, the specimen possesses strong proximo-distally running edges equipped with large triangular setae, which appear to be movable (Fig. 3A). Strong edges equipped with prominent spines or setae are, to some degree, also found on representatives of chelice- rates (Fig. 6B) and chilopods (Figs 5F inlet, 6C). Yet, similar strong edges can also be found among pterygote insects, for example orthopterans (Fig. 7A). Pterygote insects are also the best examples possessing prominent and movable setae, for example blattoids (Fig. 7B) and grasshoppers among the orthopterans (Fig. 7C). In blattoids, however, the strong edges are less definite than that seen on the cuticle fragment. Additionally the spines are not arranged in strictly proximo-distally oriented rows in blattoids (Fig. 7B). This is the case in grasshoppers (Fig. 7C) and in general in orthopterans (Fig. 7A, D). Orthopterans also have well defined edges, along which the spines arise (Fig. 7A). In conclusion, the element could represent an appendage element of a pterygote insect related to orthopterans, possibly the tibia of the metathoracic appendage. These are usually quite elongate, the specimen could in this case represent only the distal part of this element, while the proximal part would be missing. The proximal rim of the specimen could well be interpreted as representing an artificial rim caused by fragmentation. This specimen, if indeed representing an orthopteran, would represent the first insect fossil from this locality.

Specimen "Glösa-Profil KS11-099" (Fig. 3B) is a claw with denticles. Similar tarsal or pre-tarsal claws occur in various terrestrial arthropods, such as different chelicerate taxa (Fig. 6A, B), myriapods (Fig. 6C), and also insects (Fig. 7B, D). Even the dactylus of a wood louse appears very claw like (Fig. 6D). Yet, most of these claws appear to be simple claws without further armature. The only example bearing additional smaller spine-like structures like the fossil can be seen on the tarsal claw of the here documented scorpion (Brachistosternus sp.; Fig. 6B). This makes it likely that the fossil represents the tarsal claw of a scorpion, yet other affinities cannot be excluded completely.

Specimen "Glösa-Profil KS27-101" (Fig. 3C) is a cuticle fragment that provides the fewest prominent details. Still quite many details are preserved such as pores, which originally accommodated hair structures. The openings on the surface are reminiscent of those developed in trigonotarbid cuticles (Fig. 5B inlet), and similarly looking slit sensilla are common on the cuticle of arachnids in general. However, hairy surfaces - and therefore surfaces with holes after the setae are lost - are in fact common among terrestrial arthropods (e.g., Fig. 5E inlet) and make an assignment even more challenging than for the other specimens.

Specimen "Glösa-Profil KSgr.Pr.-056" (Fig. 3D) is a possibly distal sickle-shaped element with serrations along its inner edge. Such an element could be a dactylus, e.g., of an (terrestrial) isopod (Fig. 6D), but it appears rather long for such a structure. Elongate tarsal elements of insects (Fig. 7D, E) have also structural similarities to the fossil specimen. Such structures continue usually into a pre-tarsus (Fig. 7E, F), but no such structure can be discerned on 


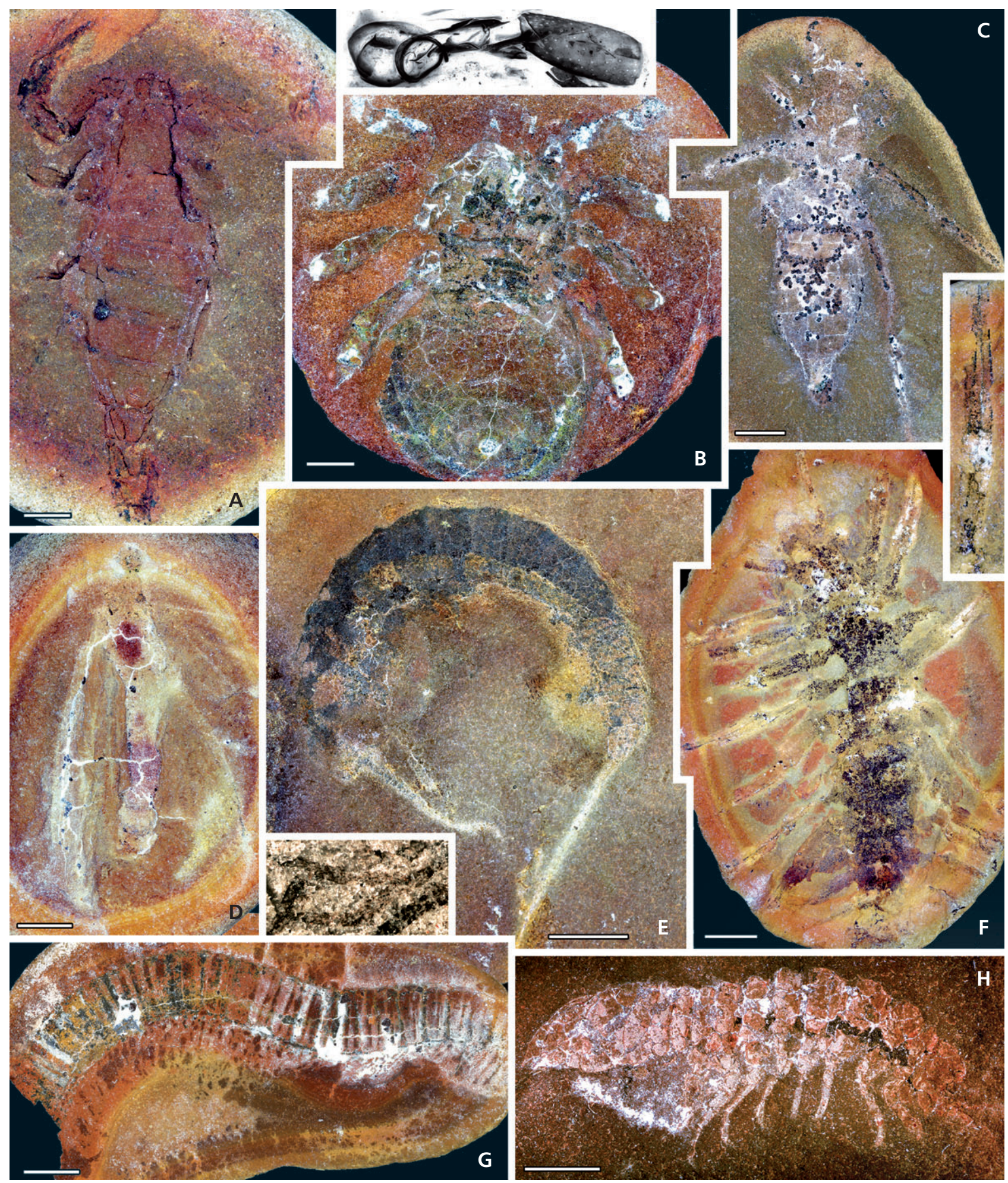

Figure 5. Different arthropods for comparison. Mainly terrestrial forms from the Carboniferous, Mazon Creek, USA. • A - ROM 45559. Scorpion, scale bar $=2 \mathrm{~mm}$. $\bullet$ B - ROM 43581. Trigonotarbid, scale bar $=3 \mathrm{~mm}$; B inlet. - RRC 3702. Cuticle remains of an appendage of a trigonotarbid from the Devonian Rhynie Chert, Scotland. • C - ROM 45545. Geralinura carbonaria, thelyphonid (whip scorpion), scale bar $=3 \mathrm{~mm}$. $・$ D - ROM 61543 . Pterygote insect, scale bar $=3 \mathrm{~mm}$. $\bullet$ E - ROM 61541. Dasyleptus sp., archaeognath (wingless insect), scale bar $=3 \mathrm{~mm} ;$ E inlet. - ROM 57075 . Close up of a leg of a Dasyleptus sp. specimen from the Early Permian of Carrizo Arroyo, New Mexico, USA. • F - ROM 45571. Scutigeromorph centipede Latzelia primordialis, scale bar $=3 \mathrm{~mm} ; \mathrm{F}$ inlet - close up of a leg of the counterpart of F. $\bullet \mathrm{G}-\mathrm{ROM}$ 61608. Diplopod, scale bar $=4 \mathrm{~mm}$. $\bullet \mathrm{H}-\mathrm{ROM}$ 47504. Hesslerella shermani, aquatic isopod, scale bar $=2 \mathrm{~mm}$. 
the fossil (Fig. 3D). The fossil could, due to its length, either represent the dactylus of a cheliped of a crustacean, or the "digitus mobilis" of a cheliceratan cheliped. As other cuticle fragments might represent scorpion remains, it is highly likely that this specimen represents the digitus mobilis of the pedipalp (claw-bearing second appendage) of a scorpion.

Arthropod Cuticle Type 1 (Fig. 4A-D) bears in its surface structure similarities to the scorpion cuticle depicted in Stankiewicz et al. (1998, fig. 2g) and also to that of Attercopus fimbriunguis (see Selden et al. 2008, their fig. 1), an arachnid probably in the evolutionary lineage leading towards modern araneans. Also Arthropod Cuticle Type 2 (Fig. 4E-G) can be compared with that of a scorpion, as depicted in Jeram (1994a, his pl. 7, figs 7, 8).

\section{General discussion and concluding remarks}

The entire fining-upward sequence of the up to $800 \mathrm{~m}$ thick Ortelsdorf Formation is dominated by compositionally immature terrigenous clastics, with subordinated thin coal seams. The lower part of the formation forms the vertical and lateral transition from a subaqueous near-shore fan delta environment into terrestrial distal alluvial fan deposits. The upper part, yielding the here described arthropod cuticles, consists of floodplain and channel deposits and deposits of local swamps forming decimetre-thick coal seams and carbonaceous shale. The very shallow but wide channel geometry and bed-load transport point to braided to anastomosing river systems. Vertically buried centimetre thick stems of lycopsids and Archaeocalamites, as well as finely rooted horizons, are not rare. Layers with current-oriented, in places chaotic trunks and twigs of Archaeocalamites, lycopsids and other plants may indicate flood events. Temporary flood plain ponds and lakes, remaining after flash-flood events, may have been spawning places of female xeanacanthid and hybodont sharks as indicated by mass-occurrences of their egg capsules. The commonness of terrestrial adapted arthropods, especially scorpions, is indicated by the cuticles; scorpion cuticles appear to be generally better preservable than those of other non-mineralised arthropods, probably due to metals enclosed in the cuticle (Jeram 2001). This abundance of remains of terrestrial arthropods fits well in the picture of an open river landscape with instable vegetation of mainly hygrophilous to mesophilous plants. Similarly, the adpression fossils of arthropods from the Berthelsdorf Formation are dominated by terrestrial forms. Most common are remains of the gigantic arthropod Arthropleura (the so far oldest known - Schneider et al. 2010) followed by trigonotarbid and phalangiotarbid arachnids (Rößler \& Schneider 1997). The preferred habitat of Arthropleura were, most likely, loosely vegetated river landscapes (Schneider et al. 2010).
Interestingly, most arachnids from the Berthelsdorf Formation have been found in a sandstone bed together with common remains of the otherwise rare mesophilous plant fossil Sphenopteris nindeliana (Rößler \& Schneider 1997). It could be assumed, that those arachnids have preferred drier areas in this river landscape.

The fossil record of Early Carboniferous terrestrial arthropods is very poor with only few localities, because Lower Carboniferous strata are mostly marine (Shear \& Kukalová-Peck 1990). Also plant localities are rather few, and their total number in central and northwest Europe barely exceeds a few dozens; most are in the late Viséan. Recently, two Tournaisian (Courceyan) localities with arthropods have been reported from southern Scotland (Tweed Basin, Scottish Borders). Both fossil associations include myriapods and scorpions (Smithson et al. 2012), which, however, have not been described in detail yet. The other locality is East Kirkton also in southern Scotland (West Lothian) (Clarkson et al. 1994). The East Kirkton deposits are Brigantian in age like the Glösa beds which are described here.

Some interesting comparisons can indeed be made with the East Kirkton lake deposits, even though this locality has yielded much more and much larger specimens than the here described Chemnitz-Glösa locality. The lake was surrounded by a gymnosperm-pteridosperm forest (Galtier \& Scott 1994, Scott et al. 1994), inhabited by a variety of terrestrial invertebrates and vertebrates (Clarkson et al. 1994). Finds of terrestrial arthropods are dominated by different ontogenetic stages $(13 \mathrm{~mm}$ to $700 \mathrm{~mm})$ of the giant Pulmonoscorpius kirktonensis, the top predator on land (Jeram 1994b). Several myriapods (Shear 1994) are known as well as one harvestman (Dunlop \& Anderson 2005). Eurypterids are represented by the up to $1.5 \mathrm{~m}$ long supposedly amphibious-terrestrial Hibbertopterus scouleri (Jeram \& Selden, 1994) (Whyte 2005). The fish fauna of the lake consisted of different actinopterygians, acanthodians and a rhizodontid sarcopterygian as well as hybodont and xenacanth sharks (Coates 1994, Paton 1994) - the latter fishes are the producers of the shark egg capsules known from the Hainichen Subgroup (Schneider et al. 2010).

The Brigantian (late Viséan) marks the start of an increased radiation of terrestrial arthropods (Ward et al. 2006) and tetrapods (Smithson et al. 2012) after a time interval reaching from the latest Devonian to the Holkerian ( middle Viséan) that is characterized by a general absence of terrestrial arthropods and tetrapods. This period is generally known as Romer's Gap. It has been hypothesized that the absence of terrestrial arthropods and tetrapods is related to low oxygen levels, which inhibited these animals with poorly developed respiratory structures from leaving the water (Ward et al. 2006). Whether this hypothesis can be maintained or whether the absence of terrestrial fauna is 

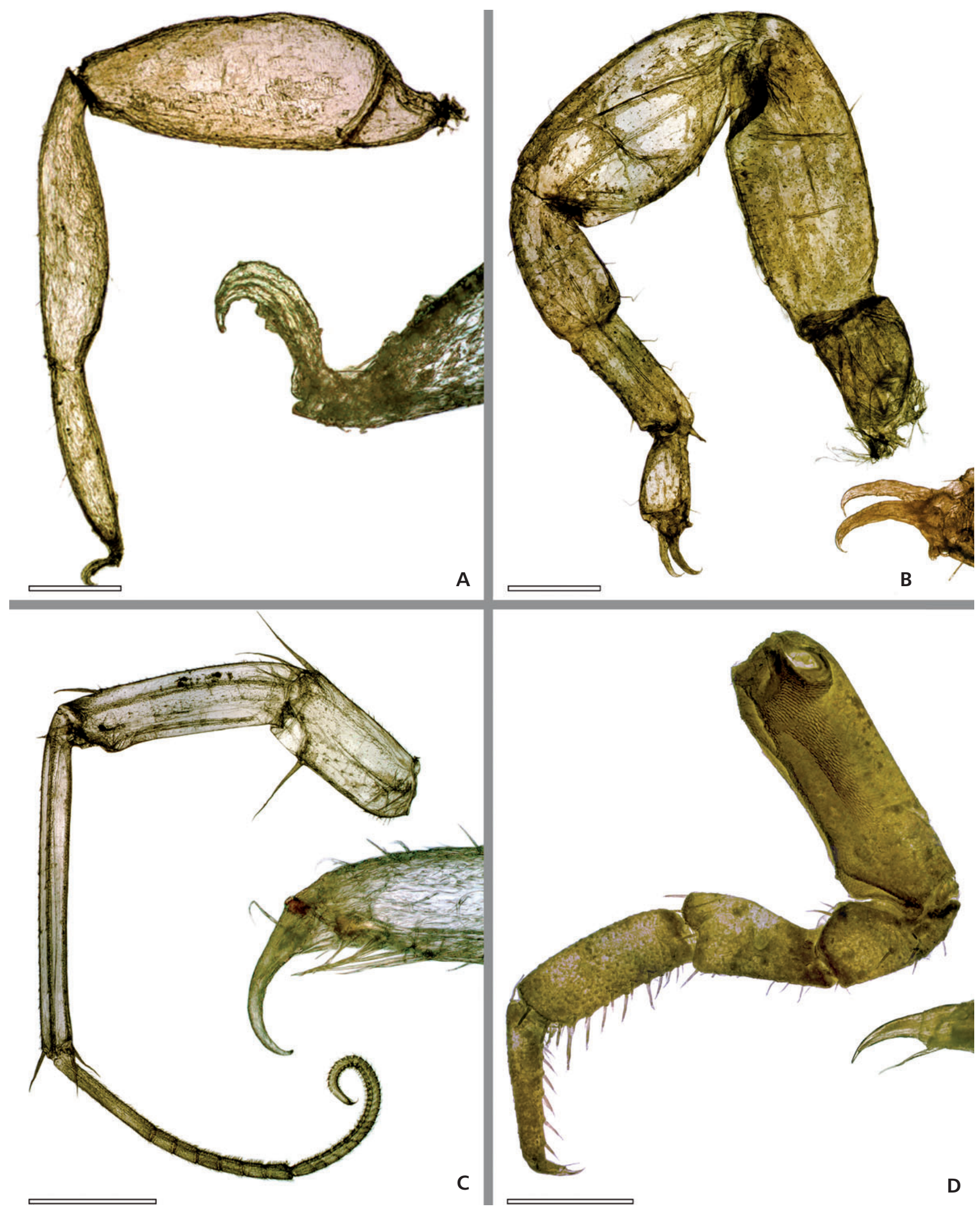

Figure 6. Macerated cuticles of extant arthropod appendages and details of their distal claws. $\cdot \mathrm{A}-$ pseudoscorpion, scale bar $=0.1 \mathrm{~mm}$. - B - Brachistosternus sp. (Scorpiones, Chelicerata), scale bar $=0.3 \mathrm{~mm} . \bullet \mathrm{C}-$ Scutigera coleoptrata (Chilopoda, Myriapoda), scale bar $=0.5 \mathrm{~mm}$. $\cdot \mathrm{D}$ - Oniscus asellus (Isopoda, Crustacea), scale bar $=0.4 \mathrm{~mm}$. 

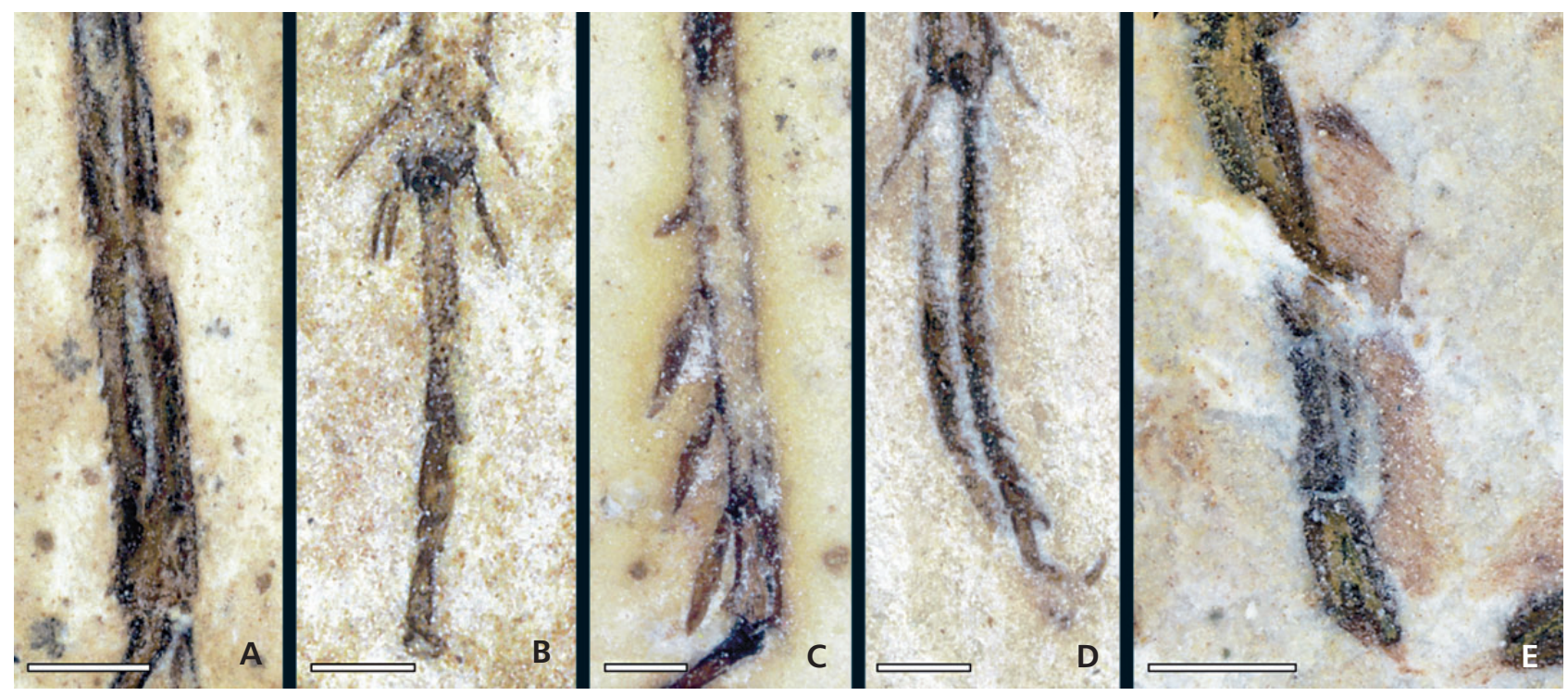

Figure 7. Legs of different insects for comparison. All specimens from the Cretaceous Crato Formation, Brazil. • A - ROM 63044. Tibia of a grylloid. Small spines along the edge appear to be movable, scale bar $=0.8 \mathrm{~mm}$. $\bullet$ B - ROM 63045. Tarsus and distal part of tibia of a blattoid. Tibia bearing large movable spines. Tarsus with paired pre-tarsal claw, scale bar $=0.4 \mathrm{~mm}$. $\bullet \mathrm{C}-\mathrm{ROM} 63046$. Tibia of a tettigoniid (grasshopper) bearing very large movable spines, scale bar $=0.5 \mathrm{~mm} . \cdot \mathrm{D}-\mathrm{ROM}$ 63047. Tarsus and pre-tarsus of an orthopteran. Tarsus elongate inward curved with an inner serrated edge. Pre-tarsal claw well-developed, scale bar $=0.5 \mathrm{~mm}$. $\bullet$ E - ROM 63048. Tarsus and pre-tarsus of a possible notonectid bug, scale bar $=0.8 \mathrm{~mm}$.

rather a lack of appropriate deposits and localities resulting in a bias of the fossil record needs to be tested. The first report by Smithson et al. (2012) suggests that many tetrapod lineages have their origin much earlier than previously thought.

Careful analyses of bulk-macerated samples from Chemnitz-Glösa resulted in the recognition of herbaceous lycopsids (Hübers et al. 2011) and the discovery of the oldest mosses (Hübers \& Kerp 2012, 2013). This contribution stresses that this method may also reveal an unexpected variety of terrestrial arthropods, and thus clearly demonstrates its great potential of sediments that at first sight only seem to contain organic debris. Even though the preservation is fragmentary, the taphocoenosis from the late Viséan Hainichen Subgroup is one of the very few occurrences of Early Carboniferous terrestrial arthropods and to our knowledge the only one from outside Scotland. Together with previously published reports on the biota of the Hainichen Subgroup these finds provide important information for the reconstruction of an Early Carboniferous terrestrial environment.

\section{Acknowledgements}

Financial support was provided by the Deutsche Forschungsgemeinschaft (DFG grant KE 584/17-1). We thank S. Schultka (Berlin) and B. Gaitzsch (Freiberg) for making part of the Glösa material available; additionally B. Gaitzsch is thanked for discussions of stratigraphy and sedimentology as well as technical support. JTH was funded by the Alexander von Humboldt Foundation as a Feodor-Lynen Postdoc fellow and by Yale University, and JTH and $\mathrm{CH}$ were additionally supported by D.E.G. Briggs (New Haven). J.-B. Caron, P. Fenton and J. Waddington (all Toronto) spent a significant amount of time in making the specimens from the Royal Ontario Museum available to JTH and $\mathrm{CH}$, for which they are heartily thanked. We are also grateful for the long-lasting support of S. Liebau (Tübingen) providing access to a Zeiss Axioskop 2 at the University of Ulm. We thank all people involved in providing freely available software such as CombineZM/ZP, Microsoft Image Composite Editor, Gimp and OpenOffice.

\section{References}

Bartram, K.M., Jeram, A.J. \& Selden, P.A. 1987. Arthropod cuticles in coal. Journal of the Geological Society 144, 513-517. DOI 10.1144/gsigs.144.3.0513

Braun, A. 1997. Vorkommen, Untersuchungsmethoden und Bedeutung tierischer Cuticulae in kohligen Sedimentgesteinen des Devons und Karbons. Palaeontographica, Abteilung A 245, 83-156.

Clarkson, E.N.K., Milner, A.R. \& Coates, M.I. 1994. Palaeoecology of the Viséan of East Kirkton, West Lothian, Scotland. Transactions of the Royal Society of Edinburgh, Earth Sciences 84, 417-425. DOI 10.1017/S0263593300006210

Clayton, G., Coquel, R., Doubinger, J., Gueinn, K.J., Loboziak, S., Owens, B. \& STREel, M. 1977. Carboniferous miospores of western Europe: illustration and zonation. Mededelingen Rijks Geologische Dienst 29, 1-71. 
CoAtes, M.I. 1994. Actinopterygian and acanthodian fishes from the Viséan of East Kirkton, West Lothian, Scotland. Transactions of the Royal Society Edinburgh, Earth Sciences 84(3-4), 317-327.

Dunlop, J.A. \& ANDERson, L.I. 2005. A fossil harvestman (Arachnida, Opiliones) from the Mississippian of East Kirkton, Scotland. Journal of Arachnology 33(2), 482-489. DOI 10.1636/04-79.1

Gaitzsch, B., Egenhoff, S., Hesse, S. \& Ehling, B.-C. 2010. Variscan Early Molasses in the Saxo-Thuringian, 311-322. In Linnemann, U., Kroner, U. \& Romer, R.L. (eds) Pre-Mesozoic Geology of Saxo-Thuringia - From the Cadomian Active Margin to the Variscan Orogen. Schweizerbart, Science Publishers, Stuttgart.

Galtier, J. \& ScotT, A.C. 1994. Arborescent gymnosperms from the Viséan of East Kirkton, West Lothian, Scotland. Transactions of the Royal Society Edinburgh, Earth Sciences 84(3-4), 261-266. DOI 10.1017/S0263593300006076

Gehmlich, M., Linnemann, U., Tichomirova, M., Gaitzsch, B. \& Bомвасн, K. 1998. Geochronologie invers gestapelter Deckenreste im Frankenberger Zwischengebirge. Terra Nostra 98(2), 52-54.

GRIMALDI, D. \& ENGEL, M.S. 2005. Evolution of the Insects. 755 pp. Cambridge University Press, New York.

Hartung, W. 1938. Flora und Altersstellung des Karbons von Hainichen-Ebersdorf und Borna bei Chemnitz (Erzgeb. Becken). Abhandlungen des Sächsischen Geologischen Landesantstalt 8, 1-140.

Haug, C., Haug, J.T., Waloszek, D., MaAs, A., Frattigiani, R. \& Liebau, S. 2009. New methods to document fossils from lithographic limestones of southern Germany and Lebanon. Palaeontologia Electronica 12(3), 6T, 1-12.

HüBers, M., Bomfleur, B. \& Kerp, H. 2011. Dispersed lycopsid cuticles from the Mississippian of Chemnitz (Saxony, Germany). Review of Palaeobotany and Palynology 167, 10-15. DOI 10.1016/j.revpalbo.2011.07.003

HÜBERS, M. \& KERP, H. 2012. Oldest known mosses discovered in Mississippian (late Visean) strata of Germany. Geology 40, 755-758. DOI 10.1130/G33122.1

Hübers, M., Kerp, H., Schneider, J.W. \& Gaitzsch, B. 2013. Dispersed plant mesofossils from the Middle Mississippian of southeastern Germany: bryophytes, pteridophytes and gymnosperms. Review of Palaeobotany and Palynology 193, 38-56. DOI 10.1016/j.revpalbo.2013.01.006

JÄGER, H. \& WIERICH, F. 2006. 6.2 Palynostratigraphie, 294-318. In AMLER, A. \& STOPPel, D. (eds) Stratigraphie von Deutschland VI. Unterkarbon (Mississippium). Schriftenreihe der Deutschen Gesellschaft für Geowissenschaften 41.

JERAM, A.J. 1994a. Carboniferous Orthosterni and their relationship to living scorpions. Palaeontology 37(3), 513-550.

JERAM, A.J. 1994b. Scorpions from the Viséan of East Kirkton, West Lothian, Scotland, with a revision of the infraorder Mesoscorpionina. Transactions of the Royal Society Edinburgh, Earth Sciences 84, 283-299.

DOI 10.1017/S0263593300006106

Jeram, A.J. 2001. Paleontology, 370-392. In Brownell, P. \& Polis, G.A. (eds) Scorpion biology and research. Oxford University Press, Oxford.

JeRAM, A.J. \& SELDEN, P.A. 1994. Eurypterids from the Viséan of
East Kirkton, West Lothian, Scotland. Transactions of the Royal Society Edinburgh, Earth Sciences 84(3-4), 301-308.

KERP, H. 1990. The study of fossil gymnosperms by means of cuticular analysis. Palaios 5, 548-569. DOI 10.2307/3514861

KeRP, H. \& KRINGS, M. 1999. Light microscopy of fossil cuticles, 52-56. In Jones, T.P. \& Rowe, N.P. (eds) Fossil plants and spores: modern techniques. Geological Society of London, London.

Máyas, G. 1920. Funde neuer Pflanzenreste aus dem Kulm von Chemnitz-Borna. Abhandlungen der Naturwissenschaftlichen Gesellschaft zu Chemnitz, 20, 55-73.

Nindel, F. 1955. Die tierischen Reste aus dem Karbon von KarlMarx-Stadt und Hainichen i.S. Geologie 4(7/8), 673-694.

PAton, R.L. 1994. Elasmobranch fishes from the Viséan of East Kirkton, West Lothian, Scotland. Transactions of the Royal Society Edinburgh, Earth Sciences 84(3-4), 329-330.

RASNITSYN, A.P. \& QUiCKE, D.L.J. 2002. History of Insects. xii + 517 pp. Kluwer Academic Publishers, Dordrecht, Boston, London.

RoLFE, W.D. I. 1980. Early invertebrate terrestrial faunas, 117-157. In PANCHEN, A.L. (ed.) The Terrestrial Environment and the Origin of Land Vertebrates. Academic Press, London.

RÖßLER, R. \& SCHNEIDER, J.W. 1997. Eine bemerkenswerte Paläobiocoenose im Unterkarbon Mitteleuropas - Fossilführung und Paläoenvironment der Hainichen- Subgruppe (Erzgebirge-Becken). Veröffentlichungen des Museums für Naturkunde Chemnitz, 20, 5-44.

RothPlETZ, A. 1880. Die Flora und Fauna der Culmformation bei Hainichen in Sachsen. Botanisches Centralblatt 1(1), 1-40.

Schneider, J.W., Hoth, K., Gaitzsch, B.G., Berger, H.J., Steinborn, H., Walter, H. \& Zeidler, M.K. 2005. Carboniferous stratigraphy and development of the Erzgebirge Basin, East Germany. Zeitschrift der Deutschen Gesellschaft für Geowissenschaften 156(3), 431-466.

DOI 10.1127/1860-1804/2005/0156-0431

Schneider, J.W., Lucas, S.G., Werneburg, R. \& Rößler, R. 2010. Euramerican Late Pennsylvanian / Early Permian arthropleurid/tetrapod associations - implications for the habitat and paleobiology of the largest terrestrial arthropod, 49-70. In LuCAs, S.G., Schneider, J.W. \& SpIELMAnN, J.A. (eds) Carboniferous-Permian transition in Canõn del Cobre, northern New Mexico. New Mexico Museum of Natural History and Science 49.

Schneider, J.W. \& Romer, R.L. 2010. The Late Variscan Molasses (Late Carboniferous to Late Permian) of the SaxoThuringian Zone, 323-346. In Linnemann, U., KRoner, U. \& Romer, R.L. (eds) Pre-Mesozoic Geology of Saxo-Thuringia From the Cadomian Active Margin to the Variscan Orogen. Schweizerbart, Science Publishers, Stuttgart.

Scott, A.C., Brown, R. Galtier, J. \& Meyer-Berthaud, B. 1994. Fossil plants from the Viséan of East Kirkton, West Lothian, Scotland. Transactions of the Royal Society Edinburgh, Earth Sciences 84(3-4), 249-260.

Selden, P.A., Shear, W.A. \& Sutton, M.D. 2008. Fossil evidence for the origin of spider spinnerets, and a proposed arachnid order. Proceedings of the National Academy of Sciences of the United States of America 105(52), 20781-20785.

DOI 10.1073/pnas.0809174106

SHEAR, W.A. 1994. Myriapodous arthropods from the Viséan of 
East Kirkton, West Lothian, Scotland. Transactions of the Royal Society Edinburgh, Earth Sciences 84(3-4), 309-316.

Shear, W.A., Bonamo, P.M., Grierson, J.D., Rolfe, W.D.I., Smith, E.-L. \& Norton, R.A. 1984. Early land animals in North America: evidence from Devonian age arthropods from Gilboa, New York. Science 224, 492-494.

DOI 10.1126/science.224.4648.492

Shear, W.A. \& KukalovÁ-Peck, J. 1990. The ecology of Paleozoic terrestrial arthropods: the fossil evidence. Canadian Journal of Zoology 68, 1807-1834. DOI 10.1139/z90-262

Smithson, T.R., Wood, S.P., Marshall, J.E. \& Clack, J.A. 2012. Earliest Carboniferous tetrapod and arthropod faunas from Scotland populate Romer's Gap. Proceedings of the National Academy of Sciences of the United States of America 109, 4532-4537. DOI 10.1073/pnas.1117332109

Stankiewicz, B.A., Scott, A.C., Collinson, M.E., Finch, P., Mösle, B., Briggs, D.E.G. \& Evershed, R.P. 1998. Molecular taphonomy of arthropod and plant cuticles from the Carboniferous of North America: implications for the origin of kerogen. Journal of the Geological Society 155, 453-462. DOI 10.1144/gsigs.155.3.0453

SterZEL, J.T. 1884. Über die Flora und das geologische Alter der
Kulmformation von Chemnitz-Hainichen. Bericht der Naturwissenschaftlichen Gesellschaft zu Chemnitz. (Festschrift) 1883-1884, 181-224.

STøRMER, L. 1970. Arthropods from the Lower Devonian (Lower Emsian) of Alken an der Mosel, Germany. Part 1: Arachnida. Senckenbergiana lethaea 51, 335-369.

StøRMER, L. 1976. Arthropods from the Lower Devonian (Lower Emsian) of Alken an der Mosel, Germany. Part 5: Myriapoda and additional forms, with general remarks on fauna and problems regarding invasion of land by arthropods. Senckenbergiana lethaea $57,87-183$.

Ward, P., Labandeira, C., Laurin, M. \& Berner, R.A. 2006. Confirmation of Romer's Gap as a low oxygen interval constraining the timing of initial arthropod and vertebrate terrestrialization. Proceedings of the National Academy of Sciences of the United States of America 103, 16818-16822. DOI 10.1073/pnas.0607824103

Whyte, M.A. 2005. Palaeoecology: A gigantic fossil arthropod trackway. Nature 438, 576. DOI 10.1038/438576a

WinsLow, M.R. 1959. Upper Mississippian and Pennsylvanian megaspores and other plant microfossils from Illinois. Illinois State Geological Survey Bulletin 86, 1-135. 